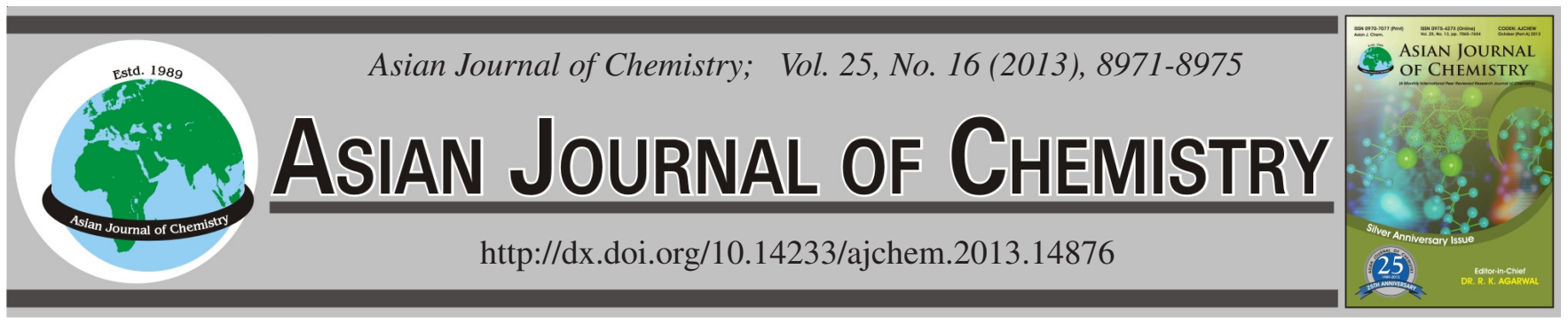

\title{
Relationship of Heavy Metals and Soil N, P, K and Total Salts in Tianshan Mountains, Central Asia
}

\author{
ZhaOYong Zhang ${ }^{1,2}$, Jilili AbUdUWAILI ${ }^{1, *}$ and FengQING JiAng ${ }^{1}$
}

${ }^{1}$ State Key Laboratory of Desert and Oasis Ecology, Xinjiang Institute of Ecology and Geography, Chinese Academy of Sciences, Urumqi, 830011, P.R. China

${ }^{2}$ University of Chinese Academy of Sciences, Beijing 10049, P.R. China

*Corresponding author: E-mail: jilil@ms.xjb.ac.cn

(Received: 26 November 2012;

Accepted: 13 September 2013)

AJC-14094

\begin{abstract}
Use Anomaly analysis, Correlation analysis and Grey relational analysis to analyze the relationship and the occurrence characters of the soil environment in the Tianshan Mountains. The results reveals that the ranking order of the heavy metal concentrations were: Co $>$ As $>\mathrm{Mn}>\mathrm{Zn}>\mathrm{Cr}>\mathrm{Cd}>\mathrm{Hg}>\mathrm{Cu}>\mathrm{Ni}>\mathrm{Pb}$. The ranking order of different vegetation types were: farmland $>$ bare land $>$ forest $>$ grassland while grey correction analysis showed the associated sequence of the heavy metals with soil $\mathrm{N}, \mathrm{P}, \mathrm{K}$ and total salt were as the following order: Total salts $>\mathrm{K}>\mathrm{P}>\mathrm{N}$. Analysis showed economic activities has put an important role on soil environment and cause the high heavy metal concentrations in many region. The users should pay much attention to the changing of the soil indicators of the soil in Tianshan mountains.
\end{abstract}

Key Words: Soil properties, Occurrence character, Tianshan mountains, Central Asia.

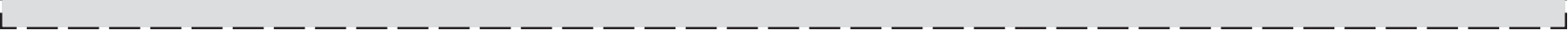

\section{INTRODUCTION}

In recent decades, the research of heavy metals in natural waters has become one of the hot areas in environmental research. Heavy metals in the natural environment have a variety of sources, including natural and anthropogenic sources ${ }^{1,2}$. It was reported that many heavy metal elements are useful and necessary to lives. However, when bioaccumulation amounts of these heavy metal exceed certain thresholds, significant harmful effects will be taken place on the biological activities of lives ${ }^{3,4}$. Recent studies ${ }^{5}$ revealed that the distribution characteristics of heavy metals cannot reflect its pollution, but also to some extent, reflect the heavy metals' sources.

Nitrogen, phosphorus, potassium and total salts are the most important soil indicators, further more nitrogen and phosphorus are necessary nutrient elements for plant growth and also the vita composition of the chlorophyll for green plants carrying out photosynthesis ${ }^{6}$. Differently potassium is not the composition of the organic compounds of plants but related to the metabolism of plants ${ }^{7,8}$. It can significantly improve the utilization of plant nitrogen and soon be transported into protein. The former studies ${ }^{9,10}$ have revealed that the heavy metal contaminations have a close relationship with other soil properties such as the ion concentrations of $\mathrm{N}, \mathrm{P}, \mathrm{K}$ and total salts. However, there is no occurrence character research about the relationship of heavy metals and soil nitrogen, phosphorus, potassium and total salts in Tianshan mountains and compare different vegetation types in Tianshan mountains. The research focuses on the following two aspects i.e., How about the heavy metal occurrence characters of this region and how the abnormal points in different vegetation types? Have the rapid economic development influenced the soil properties of the soil environment, what is the special performances in different district and how the performs with the economic factors influenced?

To achieve this, a survey of the soil environment of Tiansahn mountains was taken and the analysis were given to the soil data environment occurrence situation of heavy metals and other physical and chemical properties in Tianshan mountains, then a useful proposal (drawled up under the background of the global changes) was submitted to the corresponding institutes of the government for protecting the environment of Tianshan economic region.

\section{EXPERIMENTAL}

Tianshan mountains are located in the central Asia. The Tianshan mountains in China, being commonly called as the East Tianshan mountains, which dividing the Xinjiang into two distinctive natural sub-regions, i.e., the south and the north Xinjiang. A large amount of forests, grasslands and farmlands located in Tianshan mountains. In the desert with the high 
evaporation and the low quantities of rainfall, the soil ions decomposed become slow, there even appears "Millennium die P. euchenpica", in contrast, in the western Tianshan mountains there has a "wet island of central Asia"-Illy valley with a average rainfalls quantities of $800 \mathrm{~mm}$. Recent years, industries and agriculture production achieved rapid progress pollutions have made the soil environment appears greatly change and acid-rain even appears in many regions, causing a negative influence on the plant and crops growth.

Samples collection: In August, 2011, 60 groups of soil samples including cropland, bare land, woodland, grassland were collected from the Tianshan mountains. Each sampling site was apart from each other ca. 50 kilometers (Fig. 1). In laboratory, 10 kinds of heavy metal elements $(\mathrm{Pb}, \mathrm{Ni}, \mathrm{Cd}, \mathrm{Co}$, $\mathrm{Hg}, \mathrm{As}, \mathrm{Cu}, \mathrm{Mn}, \mathrm{Zn}, \mathrm{Cr}$ ) and soil N, P, K, total salt which can indicate the health situation of the soil environment and related closely with human activities were chosen to test.

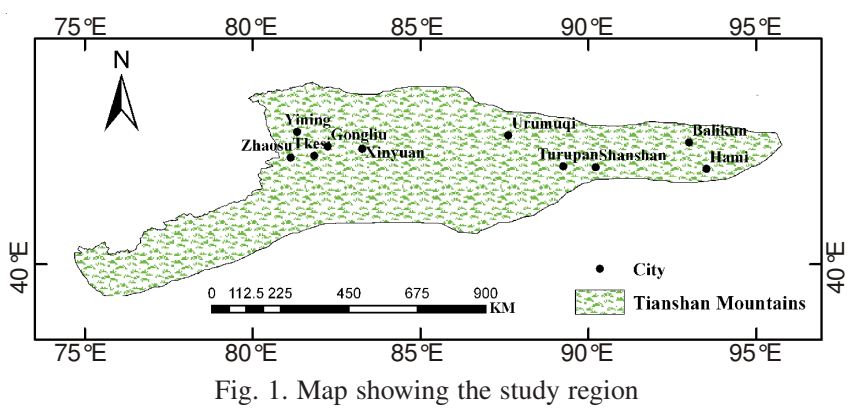

Soil properties tested: The samples detection steps were carried as the following: first of all the soil samples were airdried and then grinded, each was taking $5 \mathrm{mg}$ to nitrification in $12 \mathrm{~h}$ and then measured. All the measurements were made with an inductively coupled atomic emission spectrometer model 6500, equipped with a CID86 chip detector. The system is equipped with an integrated unit for hybrid generation. This instrument operates sequentially with both radial and axial torch configurations. The entire system is controlled by Iteva software.

The determination of $\mathrm{N}$ was made by ammonium bicarbonate method. Determination of $\mathrm{P}$ uses potassium dichromatesulfuric acid digestion. For determination of $\mathrm{K}$ was used ammonium acetate-flame photometry. The total salts measurement ranking below: first $20 \mathrm{~g}$ soil samples was weighted and added $100 \mathrm{~mL}$ deionizer water, the ratio of solid and liquid is $1: 5$, then each was in $180 \mathrm{rpm}$ oscillator oscillation for $5 \mathrm{~min}$ and stand for $0.5 \mathrm{~h}$, using the electrical conductivity method (DDS-11A conductivity meter) for testing.

Statistical methods: Typical statistical analysis, correlation analysis, Principal component analysis, Cluster analysis and grey relational analysis were used to analysis the occurrence characters of the heavy metals: $\mathrm{Mn}, \mathrm{Zn}, \mathrm{Cr}, \mathrm{Cd}, \mathrm{Hg}, \mathrm{Cu}$, $\mathrm{Ni}, \mathrm{Co}, \mathrm{As}, \mathrm{Pb}$ and nutrient elements $\mathrm{N}, \mathrm{P}, \mathrm{K}$ of the soil profile (0-5, 5-20 and 20-40 cm), all these method were carried out in the software spss 20.0.

The typical analysis is used to reflect the range, the mean and the standard deviation of the data, which can reveal the variation of them. To describe the heavy metal concentrations characteristics and detect the differences between different vegetation types directly, all heavy metal data were analyzed. Correlation analysis was used to describe the strength of the relationship of variables in different types. In the data process the Pearson correlation coefficient was chosen with all the data were changed into values and by Bivariate correlation analysis, making sided test, the Correlation matrix can be performed.

\section{RESULTS AND DISCUSSION}

Statistical analysis: Table-1 showed the standard deviation range: -1.090 to 26.355 . The differences of heavy metal contents between samples reflect the different potential sources of pollution. In the same sample, the average concentration of heavy metals following the order: $\mathrm{Co}>\mathrm{As}>\mathrm{Mn}>\mathrm{Zn}>\mathrm{Cr}>$ $\mathrm{Cd}>\mathrm{Hg}>\mathrm{Cu}>\mathrm{Ni}>\mathrm{Pb}$. Different vegetation types following as the order: Farmland $>$ Bare land $>$ Forest $>$ Desert steppe.

The analysis determined the heavy metals concentration of soil environment in Tianshan mountains are all among the National Standard of China 1995 and lower than other regions of the world ${ }^{11,12}$. Similarly, the heavy metal concentrations are also lower than the water environment of eastern China, i.e., Yangtze and Pearl rivers ${ }^{3,13}$. In contrast, the heavy metal concentrations in soil environment are higher than the oceans of east China i.e., the Bohai sea, China and the Los Angles Bay, USA, for the rapid diffusion capacity of marine. The discrete rate reflects the dispersion degree of surface heavy metals contents and the possible sources of the Tianshan mountains (the discrete rate of $\mathrm{Mn}, \mathrm{Pb}, \mathrm{As}, \mathrm{Cu}$ are higher than other heavy metals, implying the high concentrations of heavy metals in water environment). Related the backgrounds, the high heavy metals concentrations near the township and highways were obviously influenced by human activities, i.e.,

TABLE-1

DESCRIPTIVE STATISTICS OF HEAVY METALS OF SOIL IN TIANSHAN MOUNTAINS (mg/kg)

\begin{tabular}{cccccc}
\hline & Minimum & Maximum & Mean & Std. deviation & Numbers \\
\hline $\mathrm{Cu}$ & 0.271 & 1.91 & 0.412672414 & 4.723 & 60 \\
$\mathrm{Mn}$ & 0.036 & 11.414 & 1.858896552 & 6.040 & 60 \\
$\mathrm{Zn}$ & 0 & 12.568 & 1.447741379 & 3.755 & 60 \\
$\mathrm{Cr}$ & 0.491 & 4.598 & 1.324137931 & 5.229 & 60 \\
$\mathrm{~Pb}$ & 0.00 & 0.23 & 0.015293103 & 26.355 & 60 \\
$\mathrm{Co}$ & 5.375 & 91.876 & 24.09324138 & -1.090 & 60 \\
$\mathrm{Ni}$ & 0 & 0.282 & 0.055551724 & -0.901 & 60 \\
$\mathrm{Cd}$ & 0.159 & 2.546 & 0.657517241 & -1.077 & 60 \\
$\mathrm{Hg}$ & 0 & 0.559 & 0.136689655 & 2.897 & 60 \\
$\mathrm{As}$ & 0.705 & 15.502 & 5.087103448 & 7.277 & 60 \\
\hline
\end{tabular}


industry and agriculture production and emission's vehicle of the autos. Compared this, the heavy metal contents located in the forest and grassland where have good natural environment conditions are lower.

Correlation analysis: The correlation analysis shows a more complex relationship between heavy metals. In $p<0.05$ (1 detailed), the correlation coefficients of $\mathrm{Mn}$ and $\mathrm{Zn}, \mathrm{As}, \mathrm{Cd}$ are significant. Combing backgrounds with high heavy metal contents located in highway side and the township, where have high strength humans actives, they can be obviously influenced by agriculture irrigations and industries. In $p<0.05$, the correlation coefficients of $\mathrm{Cu}$ and $\mathrm{Ni}, \mathrm{Co}, \mathrm{Cd}$ are significant $(0.366$, 0.399 and 0.389 ). These sites often located in the farmland and the bare land can be also easily affected by human activities. However, in $p<0.05$, the correlation coefficients of $\mathrm{Hg}$ and $\mathrm{Ni}, \mathrm{Co}, \mathrm{Cd}$ are $-0.510,-0.257$ and -0.505 which were negative correlated, the samples have high contents of heavy metals in the highway side, where large amount of traffics emission $\mathrm{Hg}$, $\mathrm{Pb}, \mathrm{Zn}$ by the vehicle. The analysis also showed the heavy metals $\mathrm{Ni}$, As, Cr often have positive correlation in forest and the desert steppe, the heavy metals $\mathrm{Pb}, \mathrm{Hg}, \mathrm{Zn}, \mathrm{Mn}$ often have positive correlation in farmland and townships.

Analysis of soil properties in Tianshan mountains: Fig. 2 reveals that in addition to the total salts the changing trends of $\mathrm{N}, \mathrm{P}, \mathrm{K}$ are consistent in the soil profile $0-40 \mathrm{~cm}$. Combining the sites of the high concentrations of $\mathrm{N}, \mathrm{K}$, total salt they all have maximum values in farmland and the bare land where the long-term of fertilization of the agriculture has increased the concentration of the nutrient elements, meanwhile with the crop harvest over the farmland were exposed and the soil is loose, under the high evaporation, the total salt were much easily gathered in the surface. The analysis showed the total salts values are high in 20-40 and 0-5 cm, while lower in $5-20 \mathrm{~cm}$, the reason may be that the related samples sites of which were all located in the forest where have a higher vege- tation coverage and the soil of which is moist in which conditions the thick humus can easily decomposed into ions and the high ions concentrations are higher in these layers.

The analysis confirmed in the farmland and the bare land where have lower vegetation coverage and loose soil, the concentrations of total salts are higher than the grassland and the forest where the high vegetation coverage is high and the soil is moist. On the contrary, the soil N, P, K concentrations are higher in the places that have the towering vegetation coverage. The analysis also reveals that in the vertical direction the change of $\mathrm{N}$ and $\mathrm{P}$ which were the main indicators of salinization were often consist and this research have a good fit with the former research about the soil properties.

The high concentration of nutrient elements (N, P, K) in many regions are good for the plants and crops growth ${ }^{6,14}$. However, the excessive concentration of the soil (in Tianshan region this were often appears in farmland caused by longterm fertilization) can restricted the growth of certain crops (i.e., Chinese cabbage and cotton $)^{15}$. Similarly, it is shown that the high value of $\mathrm{pH}$ and nitrate may affect the salt absorption in plants growth process ${ }^{13}$.

Grey relational analysis: Grey relational analysis were used to analyze different variables, the step was ranked as the follows: first as all tested verities a grey system and site the references sequence and the comparative sequence, then calculate the grey relation degree of variables (each factor was represented as correlation degree in the analysis).

The calculate formula is:

$$
\begin{gathered}
\gamma\left(\chi_{0}(\mathrm{k}), \chi_{\mathrm{i}}(\mathrm{k})\right) \\
\frac{\min \mathrm{t} \min \mathrm{k}\left|\chi_{0}(\mathrm{k})-\chi_{1}(\mathrm{k})\right|+\xi \max \max \mathrm{k}\left|\chi_{0}(\mathrm{k})-\chi_{1}(\mathrm{k})\right|}{\mid \chi_{0}(\mathrm{k})-\chi_{1}(\mathrm{k})} \\
\gamma\left(\mathrm{X}_{0}, \mathrm{X}_{\mathrm{i}}\right)=\frac{1}{\mathrm{n}} \sum_{\mathrm{k}}^{\mathrm{n}} \gamma\left(\chi_{0}(\mathrm{k}), \chi_{\mathrm{i}}(\mathrm{k})\right)
\end{gathered}
$$
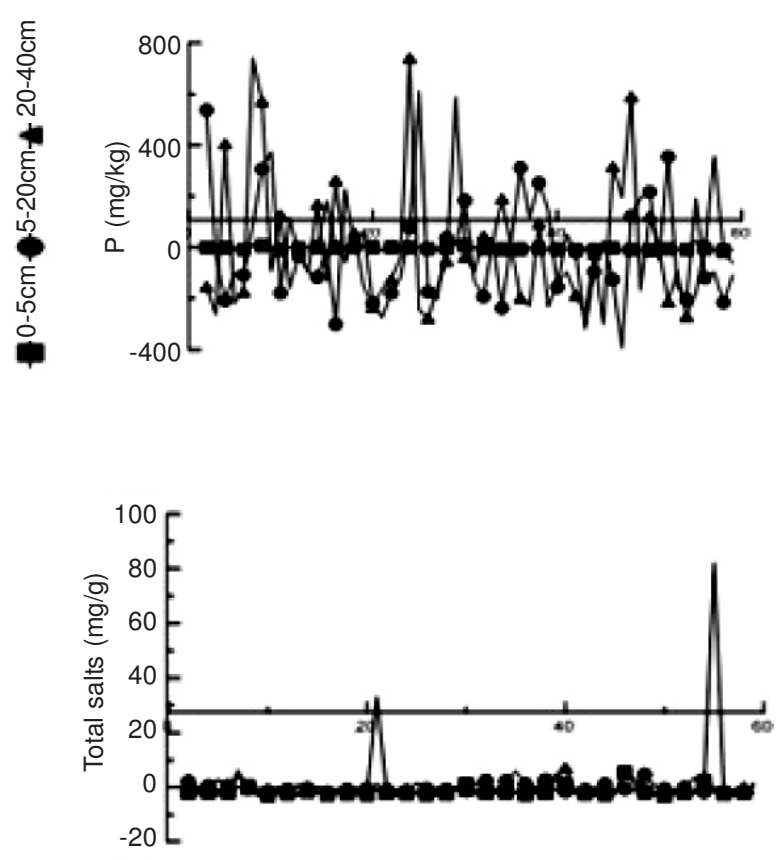

Fig. 2. Analysis of physical and chemical properties of soil profile 
In which $\gamma$ is correlation degree $\mathrm{X}_{\mathrm{i}}$ is references sequence $\mathrm{X}_{0}$ is comparative sequence $\zeta_{\mathrm{i}}$ is the distinguishing coefficientranges $(0-1)$, in this article $\xi=0.5$; $\min _{i} \min \left|X_{0}(k)-X_{i}(k)\right|$ is the minimum of absolute difference in two-tier, first each point's absolutely with the comparative sequence of $\mathrm{X}_{\mathrm{i}}$ and the references sequence of $\mathrm{X}_{0}$ should be compared, then the minimum from the minimum was selected, record as $\Delta$ min. $\max \max \left|X_{0}(k)-X_{i}(k)\right|$ is the maximum of absolute difference in two-tier, first each point's absolutely with the comparative sequence of $\mathrm{X}_{\mathrm{i}}$ and the references sequence of $\mathrm{X}_{0}$ should be compare ${ }_{c}$ ompared, then select the maximum from the maximum was selected, record as $\Delta \max .\left|\mathrm{X}_{0}(\mathrm{k})-\mathrm{X}_{\mathrm{i}}(\mathrm{k})\right|$ is the absolute difference of each point of the comparative sequence of $\mathrm{X}_{\mathrm{i}}$ and the references sequence of $\mathrm{X}_{0}$, record as $\Delta \mathrm{oi}(\mathrm{k})$.

Table- 2 reveals the influenced factors of the heavy metal concentrations, the associated sequence of the heavy metals and the soil $\mathrm{N}, \mathrm{P}, \mathrm{K}$, total salt were as the following orders: Total salts $>\mathrm{K}>\mathrm{P}>\mathrm{N}$. Which reveals the total salt concentration contributes much to the heavy metal contents, $\mathrm{N}$ and $\mathrm{P}$ which were greatly influenced by the soil ions concentration, also takes an important role in the concentration accumulations of heavy metals. The analysis also showed the gray correlations of the total salt, N, K are active (Table-3), the analysis reveals that the changing of the soil indicators, particularly, for $\mathrm{N}$ and $\mathrm{P}$ conductive have a more correlation with the heavy metals.

Heavy metals concentration in different vegetation types of Tianshan mountains: The above analysis showed that the order of the heavy metals contents in Tianshan mountains is: Farmland $>$ bare land $>$ forest $>$ grassland, which closely related to the economic development of these regions, in farmland and the bare land (highway side) the heavy metals $\mathrm{Cu}, \mathrm{Hg}, \mathrm{Pb}$ concentration are much higher than the forest and desert steppe, for the waste emission by the industries and the agriculture production, such as lead-zinc mining near the township, making the concentrations of $\mathrm{Pb}, \mathrm{Zn}$ accumulated near the soil environment; similarly, in the sample (located on the highway side), the heavy metal $\mathrm{Pb}, \mathrm{Zn}$ concentrations reach 3.86 and $10.46 \mathrm{mg} / \mathrm{kg}$, the main source of it is the combustion of leady gasoline and the zinc catalyst that auto emissions added into the gasoline for reducing the sulfur emissions ${ }^{16}$; by survey we learned the mercury-containing pesticides herbicides often used in these region during growing seasons in these region; in the forests and the desert steppe the heavy metals $\mathrm{Ni}, \mathrm{As}, \mathrm{Co}, \mathrm{Cr}$ are higher than the farmland and the highway side, combining most of sampling sites, they all located in the mountains edge and influenced little by the humans' activities, by weathering and transmission these elements contained in the rocks can be accumulated in the sampling soil environment.

Soil N, P, K and total salts values in different vegetation types of the Tianshan mountains: The analysis showed the soil N, P, K have high concentrations in the farmland and the forests, while in the desert steppe and the bare land (highway side) they are poor, with the deepening of the soil profile these nutrients showed a decreasing trend in the soil environment; in the forests of the mountains, the litter gathered at the soil

\begin{tabular}{|c|c|c|c|c|c|c|c|c|c|c|}
\hline \multicolumn{11}{|c|}{$\begin{array}{c}\text { TABLE-2 } \\
\text { CORRELATION MATRIX OF HEAVY METALS }\end{array}$} \\
\hline & $\mathrm{Mn}$ & $\mathrm{Zn}$ & $\mathrm{Cu}$ & As & $\mathrm{Pb}$ & $\mathrm{Ni}$ & $\mathrm{Cr}$ & Co & $\mathrm{Cd}$ & $\mathrm{Hg}$ \\
\hline $\mathrm{Mn}$ & 1 & - & - & - & - & - & & & & \\
\hline $\mathrm{Zn}$ & $0.876^{* *}$ & 1 & - & - & - & - & - & - & - & - \\
\hline $\mathrm{Cu}$ & 0.063 & 0.014 & 1 & - & - & - & - & - & - & - \\
\hline As & $0.649 * *$ & $0.561 * *$ & 0.197 & 1 & - & - & - & - & - & - \\
\hline $\mathrm{Pb}$ & -0.016 & -0.131 & 0.094 & -0.104 & 1 & - & - & - & - & - \\
\hline $\mathrm{Ni}$ & -0.006 & 0.102 & $0.366^{* *}$ & 0.164 & 0.003 & 1 & - & - & - & - \\
\hline $\mathrm{Cr}$ & -0.121 & -0.172 & 0.080 & 0.022 & -0.041 & $0.549 * *$ & 1 & - & - & - \\
\hline Co & 0.021 & 0.114 & $0.399 * *$ & 0.205 & 0.023 & $0.991 * *$ & $0.581 * *$ & 1 & - & - \\
\hline $\mathrm{Cd}$ & $0.347 * *$ & $0.433 * *$ & $0.389 * *$ & $0.256^{*}$ & 0.029 & $0.308^{* *}$ & 0.040 & $0.297 *$ & 1 & - \\
\hline $\mathrm{Hg}$ & 0.032 & -0.049 & $-0.272 *$ & -0.044 & -0.037 & $-0.510 * *$ & $-0.257^{*}$ & $-0.505^{* *}$ & $-0.327 * *$ & 1 \\
\hline
\end{tabular}

*The correlation was significance at $p<0.01 ; * *$ The correlation was significance at $p<0.05$.

\begin{tabular}{lccccc}
\multicolumn{7}{c}{ TABLE-3 } \\
\multicolumn{7}{c}{$\begin{array}{l}\text { TOP THREE INDICATORS OF PHYSIC AND CHEMICAL OF SOIL PROPERTIES } \\
\text { WITH A HIGH GREY CORRELATION WITH HEAVY METALS }\end{array}$} \\
\hline & $\mathrm{Elements}$ & $\mathrm{X}_{1}$ & $\mathrm{X}_{2}$ & $\mathrm{X}_{3}$ & $\mathrm{X}_{4}$ \\
\hline Correlation sort & $\mathrm{Mn}$ & 0.8440 & 0.7127 & 0.8410 & 0.9999 \\
Correlation sort & $\mathrm{Cu}$ & 0.7587 & 0.7548 & 0.7596 & 0.9998 \\
Correlation sort & $\mathrm{Zn}$ & 0.8627 & 0.8333 & 0.8515 & 0.9995 \\
Correlation sort & $\mathrm{Cr}$ & 0.8538 & 0.8582 & 0.8727 & 0.9994 \\
Correlation sort & $\mathrm{Pb}$ & 0.8733 & 0.8623 & 0.8548 & 0.9993 \\
Correlation sort & $\mathrm{Ni}$ & 0.8582 & 0.8669 & 0.8133 & 0.9955 \\
Correlation sort & $\mathrm{Cd}$ & 0.8613 & 0.8754 & 0.8512 & 0.9689 \\
Correlation sort & $\mathrm{Co}$ & 0.8669 & 0.8127 & 0.8623 & 0.9531 \\
Correlation sort & $\mathrm{Hg}$ & 0.8754 & 0.8548 & 0.8669 & 0.8890 \\
Correlation sort & $\mathrm{As}$ & 0.8548 & 0.7833 & 0.8754 & 0.8692 \\
\hline * $\mathrm{X}_{1}: \mathrm{N}(\mathrm{mg} / \mathrm{kg}), \mathrm{X}_{2}: \mathrm{P}(\mathrm{mg} / \mathrm{kg}), \mathrm{X}_{3}: \mathrm{K}(\mathrm{mg} / \mathrm{kg}), \mathrm{X}_{4}:$ Totalsalt $(\mathrm{mg} / \mathrm{g})$. & & &
\end{tabular}


surface of the forest, resulting nutrient elements accumulated in the surface and infiltration down; the total salts have high contents in the farmland and the desert steppe. It is also obvious that that the high value of $\mathrm{N}$ and $\mathrm{P}$ changes consistent in the samples, i.e., in the farmland and the desert steppe they both have the high values can be used as an important indicator of salinization $^{14,16}$.

Above analysis also showed the correlation analysis and cluster analysis are consist with the natural sources and the anthropogenic sources, such as the heavy metals $\mathrm{Ni}$, As and Cr have a strong correlation in $p<0.05$ and they all come from the natural sources, the heavy metals $\mathrm{Mn}, \mathrm{Hg}, \mathrm{Zn}, \mathrm{Pb}$, $\mathrm{Cd}$ all have a strong correlation in $p<0.05$, analysis implied they come from anthropogenic sources, meanwhile during the cluster analysis, the heavy metals $\mathrm{Pb}, \mathrm{Zn}, \mathrm{Mn}, \mathrm{Hg}$ were clustered as a group, the analysis were consistent with the correlation analysis. It is obvious that the heavy metals $\mathrm{Cu}, \mathrm{Ni}, \mathrm{Cr}$, $\mathrm{Co}$, As come from the natural sources and with a strong correction between them, at the same time, the heavy metals $\mathrm{Hg}, \mathrm{Zn}$, $\mathrm{Pb}, \mathrm{Mn}$ and $\mathrm{Cd}$ all come from the anthropogenic sources caused by unreasonable humans' activities (in industries, urban lives and agriculture).

\section{Conclusion}

The above analysis showed that the heavy metals status of Tianshan mountains are good, the heavy metals concentration of the water environment in Tianshan mountains are within the Chinese contamination standard of soil metal (Chinese State Environmental Protection Administration 1995) and also lower than other regions of the world ${ }^{6,14}$. Howevrer, this analysis also showed that during recent years, economic development has made a negative influence on the environment and the emissions of pollutants by human activities which become the main source of the high content of heavy metals of $\mathrm{Mn}, \mathrm{Hg}, \mathrm{Zn}$ and $\mathrm{Pb}$.

With the rapid progress of economy in Tianshan regions, human activities (in the form of industries, unreasonable agricultural fertilization) have played an important role in the gathering of heavy metals concentrations and other soil properties (N, P, K, total salt). In general, the environment of Tianshan mountains is very fragile and once contamination is difficult to recover.

\section{ACKNOWLEDGEMENTS}

This study was supported by the Knowledge Innovation Program of the Chinese Academy of Sciences (KZCX2-EW308; KZCX2-YW-GJ04).

\section{REFERENCES}

1. O. Babourina, K. Voltchanskii, B. McGann, I. Newman and Z. Rengel, J. Exp. Bot., 58, 651 (2007).

2. M. Barakat and E. Schmidt, Desalination, 256, 90 (2010).

3. A. Gaudry, S. Zeroual, L. Gaie, M. Moskura, Z. Boujrhal, R. Cherkaoui, E. Moursli, A. Guessous, A. Mouradi, T. Givernaud and R. Delmas, Water, Air Soil Pollut., 178, 267 (2007).

4. L. Li, X.Z. Hu, R.T. Liu, B.H. Zhou and X.C. Jin, China Environ. Sci., 30(z1) (2010) (in Chinese).

5. E.U. Onweremadu, Ph.D. Thesis, Department of Soil Science, University of Nigeria, Nsukka, Nigeria, pp. 1-330 (2006).

6. C.C. Miao and C.F. You, J. Geochem. Explor., 105, 106 (2010).

7. E. Epstein, J.M. Taylor and R.L. Chancy, Soil Sci. Soc. Am. J., 40, 647 (1976).

8. Ö. Erik, H. Olle, G. Sven, H. Nilssona and G. Smitha, Biol. Conserv., 128, 564 (2006).

9. M.I. Lone, Z.-L. He, P.J. Stoffella and X.-e Yang, J. Zhejiang Univ. Sci. B, 9, 210 (2008).

10. E. Schalscha and I. Ahumada, Water Sci. Technol., 37, 251 (1998).

11. Y.X. Song, J.F. Jia, C.P. Mao, Z.F. Yang, X.Y. Yuan, A. Ayoko and R. Frost, Geoderma, 159, 286 (2010).

12. S.F. Zhan, S.T. Peng and C.G. Liu, Bull. Environ. Contamin. Toxicol., 84, 482 (2010).

13. F. Zhou, M.Z. Tan, J. Chen and G.L. Li, Soils, 39 (2007).

14. N.N. Komarova and E.M. Sul'man, Russian J. Appl. Chem., 75, 509 (2002).

15. M.Y. Li, J.R. Xu and Z.W. Shi, Environ. Chem., 28, 716 (2009).

16. Y.L. Wang, X.Y. Qiu, Y.J. Zhu, Q.L. Zhang, T.C. Guo, M.C. Wang and Y.X. Xie, Acta Agric. Boreali-Occidentalis Sin., 20 (2011). 